\title{
Digest of Important Canadian Cases Reported in 1972 in the Fields of Public International Law and Conflict of Laws
}

Jean-Gabriel Castel

Osgoode Hall Law School of York University, castel@fake.osgoode.yorku.ca

Source Publication:

Canadian Yearbook of International Law. Volume 11 (1973), p. 347-381.

Follow this and additional works at: https://digitalcommons.osgoode.yorku.ca/scholarly_works

Part of the Conflict of Laws Commons, International Law Commons, and the Public Law and Legal Theory Commons

(c) $($ ) $\Theta \Theta$

This work is licensed under a Creative Commons Attribution-Noncommercial-No Derivative Works 4.0 License.

\section{Recommended Citation}

Castel, Jean-Gabriel. "Digest of Important Canadian Cases Reported in 1972 in the Fields of Public International Law and Conflict of Laws." Canadian Yearbook of International Law 11 (1973): 347-381.

This Commentary is brought to you for free and open access by the Faculty Scholarship at Osgoode Digital Commons. It has been accepted for inclusion in Articles \& Book Chapters by an authorized administrator of Osgoode Digital Commons. 


\title{
Digest of Important Canadian Cases Reported in 1972 in the Fields of Public International Law and Conflict of Laws
}

\author{
Compiled by \\ J. - G. CASTEL
}

\section{Public International Law}

Confuscation de biens situés au Cuba par le Gouvernement Cubain - Revendication - Québec, Cour d'Appel

Trudeau et Bernard v. Juelle et Juelle, [ 1972] C.A. 870.

La confiscation est valable selon la lex situs car en l'absence de preuve contraire, le gouvernement cubain a rempli les formalités nécessaires à l'exercice du pouvoire de confiscation selon les dispositions de l'article 24 de la Constitution de ce pays. En conséquence, le gouvernement cubain a acquis la propriété des chevaux et partant, des chevaux revendiqués issus des chevaux confisqués.

Extradition-Procedure - Political Crimes-Commission Evidence - Ontario County Court

Re State of Wisconsin and Armstrong, [1972] 3 O.R. 46r, 28 D.L.R. (3d) 5 I 3,8 C.C.C. (2d) 444 -

In extradition proceedings, the respondent, who was charged by the State of Wisconsin with arson and murder in the bombing and resultant death of a person on a university campus was denied the sanctuary afforded by s. 2 I of the Extradition Act, R.S.C., 1970, c. E-2 I, which provides that no fugitive is liable to surrender if it appears that the offence in respect of which proceedings are taken is one of a political character. The onus is on the requesting state to show that the offence is not of a political character.

As to the meaning of "offence of a political nature," the Court applied Viscount Radcliffe's formula as articulated in Schtraks v. Gov't. of Israel, [ 1964$]$ A.C. 556, at 59 I-92: 
"In my opinion the idea that lies behind the phrase 'offence of a political character' is that the fugitive is at odds with the state that applies for his extradition on some issue connected with the political control or government of the country. The analogy of 'political' in this context is with 'political' in such phrases as 'political refugee' 'political asylum' or 'political prisoner'. It does indicate, I think, that the requesting State is after him for reasons other than the enforcement of the criminal law in its ordinary, what I may call its common or international, aspect. It is this idea that the judges were seeking to express in the two early cases of In re Castioni and In re Meunier when they connected the political offence with an uprising, a disturbance, an insurrection, a civil war or struggle for power: and in my opinion it is still necessary to maintain the idea of that connection. It is not departed from by taking a liberal view as to what is meant by disturbance or these other words, provided that the idea of political opposition as between fugitive and requesting State is not lost sight of: but it would be lost sight of, I think, if one were to say that all offences were political offences, so long as they could be shown to have been committed for a political object or with a political motive or for the furtherance of some political cause or campaign. There may, for instance, be all sorts of contending political organisations or forces in a country and members of them may commit all sorts of infractions of the criminal law in the belief that by so doing they will further their political ends: but if the central government stands apart and is concerned only to enforce the criminal law that has been violated by these contestants, I see no reason why fugitives should be protected by this country from its jurisdiction on the ground that they are political offenders."

In coming to the decision that the offence was not of a political character regard was had to the fact that the university whose building was bombed had a policy which forbade classified research on campus, and did no specific work for the army. Regard also was had to the fact that most of the accused's witnesses who fully admitted political activity of the kind they suggested was associated with the bombings required political asylum.

In procedural matters, depositions under oath were permitted to prove the prima facie case as required by s. 13 of the Extradition Act without the necessity of having viva voce evidence called. However, the extradition court had no power to order a commission to take the evidence of witnesses out of Canada with a view of examining the deponents whose depositions were filed in support of the 
application since the Criminal Code ss. 637 (b), 640 ( I) (a) limits the application for a commission to a judge of the court before which the accused is to be tried.

\section{Extradition-Procedure - Review-New Brunswick Court of Appeal}

Re Milbury and R. (1972), 25 D.L.R. (3d) 499.

Section I8(a) of the Federal Court Act, S.C., 1970-71, c. I excludes the jurisdiction of provincial courts by granting exclusive jurisdiction to the Trial Division of the Federal Court to review by way of prerogative writ or to grant relief from a decision of a federal board, commission, or tribunal. The applicant was committed for surrender to a foreign state for an extraditable offence by a County Court Judge sitting as persona designata under the Extradition Act, R.S.C., I970, c.E-2 I. It was held that for the purposes of that hearing the Judge, as persona designata, was a federal tribunal as defined by $\mathbf{s . 2}(\mathrm{g})$ of the Federal Court Act and accordingly the provincial court of appeal had no jurisdiction to issue a writ of certiorari.

\section{Extradition - Procedure - British Columbia Supreme Court}

Re Whipple, [1972] 2 W.W.R. 613.

In extradition proceedings, production of a copy of the record of sentence of the court before which the conviction took place is not a condition precedent to the making of the extradition order. The respondent in this case was convicted by a jury in the United States of conspiracy to traffic in narcotics but absented himself before sentence was pronounced. He could not avail himself of the provision in Article VII of the Imperial Order in Council of 1890 (the extradition arrangement with the U.S.A.) requiring production before the extraditing Court of a copy of the record of conviction and sentence, since such provision must be read with reference to the provision in the same article exempting from extradition a person who had already served his sentence and to the principle that such Conventions are to be given a fair interpretation according to the intention of the contracting parties. 
Extradition - Procedure - Ontario High Court

Re Armstrong and State (1972), 7 C.C.C. (2d) 33 I.

An application for an order prohibiting the county court judge who had heard a request for a remand of an extradition proceeding and who had, prior to entering the courtroom on that occasion, ordered the court cleared of the public with the exception of the press and the accused's father, from taking any further action in the applicant's extradition proceedings was dismissed as premature since what took place on the relevant date was an appearance before an extradition judge for the purpose of remand and the county court judge was not yet seised of the extradition proceeding. However, guidelines were discussed concerning the exclusion of the public in extradition proceedings. The right to exclude the public found in sections 442 and 465 of the Criminal Code was incorporated into the Extradition Act by virtue of sections 9 and I $_{3}$ of that act which prescribe that the procedure before a judge sitting on an extradition matter is the same as that before a justice of the peace on a preliminary hearing of an indictable offence. The general rule is the open court; with the closed court as the exception provided the judge indicates on the record why he is excluding the public from a judicial proceeding. Furthermore, the judge should, if possible, conduct a hearing in the presence of all counsel, the accused, and the official court reporter on the question of exclusion.

International Criminal Law-Commission Evidence-Witnesses out of Canada - Jurisdiction - Procedure - Ontario Court of Appeal

Re Regina and Lester, [1972] 2 O.R. 330.

Where new and important evidence comes to light which could not possibly have been known at the time of the trial and which if available at trial could not have been denied to the applicant on a central issue in the determination of his guilt or innocence, the evidence should be available to the Court of Appeal in the event that it permits the applicant to refer to it. While the relief sought cannot be granted under s. 6 ro of the Criminal Code since the witnesses are residents of a foreign jurisdiction, an appeal is a "proceeding" within the meaning of ss. 637 and 640 and the order sought may be made thereunder. 
Citizenship - Applications by Husband and Wife - Residence Requirements - Citizenship Appeal Court

Re Sook Ying Lum, [1972] F.C. 3.

An application for citizenship was rejected on the ground that when she made her application she was not the wife of a Canadian citizen and did not meet the residence requirements of s. IO(I) (c) (i) of the Canadian Citizenship Act, R.S.C., r970, c. C-19.

Applicant appealed on the ground that as her husband who had applied for citizenship at the same time, had been granted citizenship, she was relieved by s. Io(I) (c) (iii) of the residency requirements imposed under s. Io(I) (c) (i).

Citizenship - Refusal to Grant - Judicial Review of Ministerial Discretion - Ontario High Court

Dowhopoluk v. Martin et al. ( I97 I), 23 D.L.R. (3d) 42.

Citizenship is a privilege and not a right. It would be injurious to the public interest for the courts to inquire as to whether the minister of the Crown has properly exercised his discretion in a matter which flows from royal prerogative. Subsections 2 (b) and (e) of the Canadian Bill of Rights do not apply since rights in existence are not at issue.

\section{Citizenship - "Resided in Canada" - Federal Court}

Blaha v. Minister of Citizenship $\mathbb{E}$ Immigration, [197 I] F.C. $52 \mathrm{I}$. The words "resided in Canada" in s. I ( 1 ) (b) of the Canadian Citizenship Act, R.S.C. 1970, c. C-19, mean actual physical residence in Canada. This case was followed in Re Goldston, [1972] F.C. 559 (Citiz. App. Ct.).

Immigration - False Statement by Applicant - Ontario Court of Appeal

R. v. Gloede (I 97 I), 5 C.C.C. (2d) 545, [1972] I O.R. 868.

Section $50(e)$ of the Immigration Act, R.S.C., I952, c. 325 , now R.S.C., 1970, c. I-2, which makes it an offence for an applicant for immigration not to answer truthfully all questions put to him at an examination under the Act, applies regardless of whether the ap- 
plicant when making the statements is sworn, or affirming, or declaring.

Immigration - Application for Permanent Residence by Non-immigrant-Requirement of Medical Certificate - Supreme Court of Canada.

Podlaszecka v. Minister of Manpower \& Immigration (1972), 23 D.L.R. (3d) 33 r.

Section 29( $\mathrm{I})(b)$ of the Immigration Regulations, Part I, SOR/ 62-36, provides that "no immigrant shall be granted landing in Canada if he is not in possession of a medical certificate, in the form prescribed by the Minister." This section does not, however, apply to a person who enters Canada on a visitor's visa and subsequently applies for permanent admission. While such a person comes within section 7(3) of the Immigration Act, R.S.C., I952, c. 325 and therefore "ceases to be a non-immigrant" and is "deemed to be a person seeking admission to Canada," he is not specifically designated as an "immigrant," which word is defined by section $2(i)$ as meaning "a person who seeks admission to Canada for permanent residence."

Immigration - Dismissal of Application for Permanent Admission to Canada-Effect of Breach of Statute on further Application for Permanent Admission - Supreme Court of Canada

Leiba v. Minister of Manpower $\mathcal{E}$ Immigration (1972), 23 D.L.R. (3d) 476 .

The appellant first entered Canada under a non-immigrant visa as a visitor for a period ending January 2, I968. On October 4, 1967 , within a week after his arrival, he applied for permanent residence. He was assessed by an immigration officer according to the prescribed norms of assessment, but his rating was below the required standard. He was not then represented by counsel, nor was he fluent in English or French. By letter of January 19, I968, the appellant was advised that his application was refused for failure to meet the required level of assessment, and he was requested to leave Canada by February 2, 1968, on pain of the initiation of an inquiry which might lead to deportation. This so-called "check-out" letter was an administrative practice, nowhere expressly authorized by the 
Immigration Act, R.S.C., 1952, c. 325 , s. 23 or the Immigration Regulations, SOR $/ 62-36$, s. 34 (3) (d). Section 23 of the Act in fact provided that where an immigration officer was of opinion after examining an applicant for admission for permanent residence, that it would be contrary to the Act or Regulations to admit him, "he may cause such person to be detained and shall report him to a Special Inquiry Officer." The appellant left Canada but was re-admitted on February 2, 1968, for a temporary period ending March 2, 1968. An application for permanent residence was lodged on September 25, 1968. No fresh assessment was made and the application was refused under section $34(3)(d)$ of the Regulations on the ground that it had not been made before the expiry of the period ending March 2, 1968 . This was reported to a Special Inquiry Officer in accordance with section 23 , and an inquiry was directed. The result of the inquiry was an order of deportation on the ground of non-compliance with section $34(3)(d)$ of the Regulations. An appeal was taken on the ground that the appellant had been under-assessed on October 4,1967 because of a failure to provide him with an interpreter. The appeal was dismissed, the Appeal Board holding that the order was valid in that the appellant sought to apply for permanent residence long after the expiry of his nonimmigrant status on March 2, 1968. Appellant's motion to reopen the case was dismissed, but on appeal it was allowed. The Appeal Board should have set aside the deportation order and the proceedings which led to it so as to leave appellant free to have the proceedings on his first application properly concluded, or it should have directed the Special Inquiry Officer who made the deportation order to reopen the hearing and treat it as flowing from the first application or should have itself acted on that view, with the result that the appellant could properly claim to be re-assessed for permanent admission. This was not a case where the appellant had not pursued his rights of appeal against a deportation order and had instead made a fresh application for permanent residence which was out of time under section $34(3)(d)$ of the Regulations. The appellant could not appeal in respect of his first application because the examining officer did not carry out his statutory duty under section 23 of the Act to report the appellant to a Special Inquiry Officer. Although the appellant did not take steps to compel an inquiry under section 23 in respect of his application of October 4, I 967 , the breach of statutory duty by the examining officer could not be as lightly set aside as was done in relation to the application 
of September 25,1968 , by reliance on his failure to observe the time limit specified in section $34(3)(d)$ of the Regulations. The requirement of this provision was met by him in his original application and were it not for what was in effect a deportation order, made without authority under the "check-out" letter, his application would have proceeded in regular course.

Immigration - Offences under Immigration Act - Limitations British Columbia Supreme Court

R. v. Gill, [197 I] 5 W.W.R. 722, 22 D.L.R. (3d) 724.

Section $5^{2}$ of the Immigration Act, R.S.C. 1970, c. I-2, provides a limitation period of 3 years for the institution of proceedings for an offence under the Act. Although the offence may be triable by summary conviction procedure, the 3-year limitation period applies rather than the 6 months' period provided in section 721 of the Criminal Code, R.S.C., I970, c. C-34. The Act, itself a complete code, is embraced by the words "Except where otherwise provided by law" contained in section $72 \mathrm{I}$ of the Criminal Code.

Immigration - Deportation - Special Inquiry Officer and Immigration Appeal Board not Making Proper Inquiry-Quebec Court of Appeal

Re Horowitz and Minister of Manpower \& Immigration (1972), 24 D.L.R. (3d) 370.

H., a landed immigrant, was subsequently arrested on the ground that he had given false information in his application for admission to Canada contrary to section I9 ( I) (e) (viii) of the Immigration Act, R.S.C., 1952, c. 325, and that he had been convicted of a crime involving moral turpitude. $H$. had been found guilty of negligent driving and assault while living in the U.S.A. He had appealed and entered a plea of nolo contendere which had been accepted by the court and had been ordered to pay fines. The special inquiry officer, who admitted that he was not familiar with a plea of nolo contendere, which, $H$. contended, was not the same as a guilty plea, ordered $\mathrm{H}$. to be deported. An appeal was dismissed by the Immigration Appeal Board. On an application for certiorari, the court granted the application. Section 3 I (3) gave the Appeal Board "full power to consider all matters" and section II (3) (e) empowered a 
special inquiry officer to "do all ... things necessary to provide a full and proper inquiry." In fact, neither the special inquiry officer nor the Appeal Board had inquired into H.'s contention that the nolo contendere plea was not a guilty plea and that therefore he had not been convicted. Thus, the officer and the Board had omitted to do something essential to the exercise of their jurisdiction.

\section{Immigration - Deportation - Evidence - Error in Law - Supreme Court of Canada}

Woolaston et al. v. Minister of Manpower and Immigration (1972), 28 D.L.R. (3d) 489.

An appeal to the Supreme Court of Canada from a decision of the Immigration Appeal Board affirming an order of deportation was dismissed upon the ground that the alleged error of law relied upon by the appellant was actually a matter of fact upon which no appeal to this court lies.

The appellant had been in Canada on a non-immigrant student visa which expired on December 5 , I 968 . On November 2, 1968 she married another non-immigrant visitor. She did not formally apply for permanent admission until April 3, 1969 at which time the immigration authorities refused to process the application and initiated deportation proceedings. The deportation order made against her was on the ground that she was not a qualified applicant for permanent admission under the Regulations to the Immigration Act, not being lawfully in Canada at the time of her formal application for admission by reason of the expiry of her visa. The appellant gave evidence before a Special Inquiry Officer to the effect that prior to the expiry date, she had gone to the Immigration Office to advise an officer of her intention to make application for permanent admission but was prevented from making a formal application by being informed that she could not apply on account of her marriage and would be included in her husband's application; he was subsequently refused admission. The Immigration Appeal Board affirmed the deportation order without mentioning the above evidence in its reasons. The question before the Supreme Court of Canada was whether the Board had erred in law in failing to take into consideration the uncontradicted evidence. The court was unable to conclude that the Board had ignored the evidence and had thereby committed an error of law. The evidence was clearly part 
of the record before the Board and was thus to be weighed as to its reliability and cogency along with other evidence in the case and it was open to the Board to discount it or to disbelieve it. The fact that it was not mentioned in the Board's reasons is not fatal to its decision.

Deportation Order - Jurisdiction of Courts to Grant CertiorariImmigration Appeal Board Act, S.C. Ig66-67, c. 9o-Supreme Court of Canada

Pringle v. Fraser (1972), 26 D.L.R. (3d) 28, reversing [197 I] 2 O.R. 749, ig D.L.R. (3d) 129 .

The Supreme Court of Canada upheld the original judgment and denied jurisdiction in the Supreme Court of Ontario to entertain certiorari proceedings to quash a deportation order made under the Immigration Act. The combination of the new scheme of review and appeal from initial deportation orders provided for by the establishment of the Immigration Appeal Board under the Immigration Appeal Board Act and the privative clause in section 22 of the Act giving "sole and exclusive jurisdiction to hear all questions of law and fact" arising in relation to the making of deportation orders to the Board is sufficient to oust the jurisdiction of the Supreme Court.

Deportation order - Inquiry - Immigration Inquiry Reg. SOR \# 67-62I, s. II - Federal Court of Appeal

Re Rodney and Minister of Manpower and Immigration (1972), 27 D.L.R. (3d) $75^{6 .}$

A wife, called as a witness at an inquiry, was informed that she and the child could be included in a deportation order made against her husband and s. I I of the Regulations was read to her. She was then asked to establish why she should not be included in an order and subsequently, an order including her and the child was made. On appeal from the Immigration Appeal Board, dismissing an appeal relating to the wife and child, the Federal Court of Appeal held that the appeal should be allowed. Not only had the wife been given no advance notice that an order might include her, but she was merely informed of this, while a witness in proceedings framed exclusively against her husband. She was thus confronted with a 
situation with little or no time to appreciate what action had to be taken to protect her interests.

\section{Aliens - Deportation - Immigration Appeal Board-Compas- sionate or Humanitarian Grounds - Supreme Court of Canada}

Grillas v. Minister of Manpower and Immigration (1972), 23 D.L.R. (3d) I.

The appellant, a Greek national, entered Canada illegally and was ordered deported by a Special Inquiry Officer. An appeal to the Immigration Appeal Board seeking an order under s. I5 ( I) (b) of the Immigration Appeal Board Act, I966-67 (Can.), c. 9o (now R.S.C., 1970, c. I-3), directing that the execution of the deportation order be stayed or quashed on the ground that reasonable grounds existed for believing that if execution of the order was carried out the appellant would be punished for activities of a political character was dismissed by the Board. A motion was brought to have the Board reopen the appeal on the ground that evidence respecting certain visits by the Greek police to the home of the appellant's mother and respecting the previous political activity of the appellant in Greece was not available at the original hearing of the appeal, and that the Board should reconsider its decision in the light of this evidence. The Board, consisting of one new member who did not sit at the original hearing, dismissed the appeal. On appeal from that decision on the ground that the Board had improperly taken into account as evidence statements which were made at the hearing by counsel for the respondent, it was held (Martland and Laskin JJ., dissenting) that the appeal should be dismissed. The statements made were not treated as evidence but rather as a plausible explanation for the visits of the Greek authorities, an explanation which did not indicate an intention to punish the appellant, if apprehended, for his political activities, but rather which suggested that the Greek authorities were, in co-operation with Canadian immigration officials, seeking to determine the location of the appellant in Canada in order that he might be advised to seek admission to Canada in the proper manner. As there was no evidence before the Board to contradict this explanation, the Board did not err in taking it into account in reaching its decision. 
Aliens - Deportation - Immigration Appeal Board - Compassionate or Humanitarian Jurisdiction - Supreme Court of Canada

Boulis v. Minister of Manpower and Immigration (1972), 26 D.L.R. (3d) 2 I6.

The duty imposed on the Immigration Appeal Board under $\mathbf{s}$. ${ }_{15}(\mathrm{I})(b)(\mathrm{i})$ of the Immigration Appeal Board Act, I966-67 (Can.), c. 9o, now R.S.C., I970, c. I-3, to deal with claims for political asylum and to apply compassionate or humanitarian considerations to claims of lawful entry into Canada is a sensitive one and the Parliament of Canada has made it clear that the decision should not rest on random or arbitrary discretion but rather on the basis of evidence the relevancy and cogency of which the Board is to pronounce as a judicial tribunal. However, in exercising its appellate jurisdiction over decisions of the Board, the Supreme Court of Canada ought not to interfere with the weight assigned by the Board to evidence before it. It is enough if the Board in its reasons shows a grasp of the issues that are raised by s. ${ }_{5}(\mathrm{I})(b)$ and of the evidence addressed to them.

Income Tax - Non-resident Company-Canada-Ireland Income Tax Agreement - Supreme Court of Canada

Minister of National Revenue v. Tara Exploration and Development Co. Ltd. (1972), 28 D.L.R. (3d) 135.

All the management and executive decisions relating to the conduct and control of the respondent company were made in Ireland. The company, though incorporated in Ontario, had no employees at its head office in Toronto, and no person resident in Canada had the authority to contract or conduct business on its behalf. The company maintained a bank account in Toronto but all important decisions in respect of it were made in Ireland. The Canada-Ireland Income Tax Agreement Act, 1955 (Can.), c. Io, provided an exemption from tax for an Irish enterprise unless "engaged in trade or business in Canada through a permanent establishment situated therein." It was further provided that if the enterprise was so engaged tax might be imposed on profits but only on so much of them as was "attributable to that permanent establishment." The Minister assessed for income tax the profit made by the company on the purchase and sale of shares of another Canadian company, the de- 
cision to buy the shares having been made in Ireland. The company appealed successfully to the Exchequer Court. On further appeal by the Minister, The Supreme Court of Canada dismissed the appeal on the ground that the office in Toronto was probably not a "permanent establishment" within the meaning of the treaty, and even if it were, the profit made on the sale of the shares was not "attributable" to such establishment.

\section{Confict of Laws}

Driver's Licence Issued in Other Jurisdiction - Suspension - Saskatchewan Court of Appeal

R. v. Huffman, [1972] I W.W.R. 96 .

A licence issued in Manitoba is liable to suspension under the Vehicle Act of Saskatchewan as a "subsisting operator's licence."

\section{Succession Duties - Share Certificates - Situs - British Columbia Court of Appeal}

First National Bank of Nevada v. Minister of Finance (1972), 5 W.W.R. 443 .

The respondent bank was the personal representative of an owner of 400 shares in a British Columbia corporation who was resident and domiciled in the State of Nevada at the time of his death. The share certificate was kept in Nevada. However, section 94 (I) of the British Columbia Companies Act required that the shares owned by deceased members be transferred only at the principal register, i.e. in the province of British Columbia as opposed to one of the branch offices. Accordingly, the Minister of Finance considered that the situs of the shares was within the province and levied succession duty on them. The bank successfully appealed the imposition of taxation. (Sub. nom. Re Wolfenden Estate, [197I] 5 W.W.R. 168.) The British Columbia Court of Appeal here dismissed the appeal from that decision, holding that section 94 ( 1 ) of the British Columbia Companies Act was ultra vires the provincial legislature, because it was in pith and substance an unlawful attempt under the guise of legislation in respect of a provincially incorporated company, to alter the situs of shares of a deceased shareholder and to subject them to provincial succession duties. 
Compétence des Tribunaux - Possession de Biens dans la Province de Québec

Code de Procédure Civile, art. 68(1) - Québec, Cour Provinciale

M. Botner \& Sons Inc. v. Southern Pacific Co., [1972] R.P. 7.

Les sommes dues par le Canadien National et le Pacifique Canadien à la défenderesse sont des biens situés dans la province puisqu'il s'agit de dettes actives, attachées comme telles à la personne du débiteur où il se trouve, soit à ces deux compagnies ayant leur siége social à Montréal.

\section{Compétence des Tribunaux - Demande Reconventionnelle}

Code de Procédure Civile, arts. 163, I68, $172-Q u e ́ b e c$, Cour d'Appel

Yoshioka $\mathfrak{E}$ Crea Ltd. v. Interprex Dairy Products Ltd. et al., [1972] C.A. 686.

Une société étrangère domiciliée au Brésil n'ayant aucune place d'affaires au Québec et n'y transigeant aucune affaire qui poursuit au Québec une société domiciliée dans cette province ne saurait se plaindre si cette dernière, en défense, utilise le même tribunal pour une demande reconventionnelle. Il n'est d'ailleurs pas exact de prétendre que la demanderesse n'a pas de biens dans la province de Québec, ne serait-ce que la créance qu'elle prétend exercer contre le défendeur.

Jurisdiction - Possession of Property within the Province - Quebec Superior Court

Ross and Pronghorn Petroleum Corporation Ltd. v. Tsumura and Others, [1972] C.S. 194.

Shares in "street form" held in Quebec for the benefit of and in trust for the defendant gives the Quebec courts jurisdiction over him. The broker had possession of the shares for the benefit of the defendant who was then in possession of property in the Province according to article 68(I) of the Code of Civil Procedure. 
Sale of Land Outside Jurisdiction - Action for Specific Performance - New Brunswick Supreme Court - Appeal Division

Ward v. Coffin (1972), 27 D.L.R. (3d) 58 (1972), 4 N.B.R. (2d) $48 \mathrm{I}$.

Since the defendant resided in New Brunswick and since a claim for specific performance is an action in personam, the court had jurisdiction to entertain the action even though the land was situated in the province of Quebec.

Jurisdiction - Procedure - Third Party Proceedings - Service Ex Juris - Ontario Supreme Court Master's Chambers

Dow Chemicals of Canada Ltd. v. Pritchard Canadian Ltd. et al., [1972] 2 O.R. 399 .

Where a foreign defendant enters an appearance after unsuccessfully attacking the order permitting service ex juris and third party proceedings are brought against the foreign defendant and a foreign third party by a co-defendant and service is made on the foreign defendant in the main action, the action is not "properly brought against another person duly served within Ontario" within the meaning of Rule 25 ( I ) (j) so as to permit service ex juris of the third party notice on the foreign third party.

Jurisdiction - Service Ex Juris - Breach of Contract-Forum Non Conveniens - Northwest Territories Territorial Court

Cadillac Explorations Ltd. (N.P.L.) v. Penarroya Canada Ltee et al. (1972), 30 D.L.R. (3d) $3^{26 .}$

Service of Writ Ex Juris - Tort Action - British Columbia Supreme Court in Chambers

Leigh Marine Services Ltd. v. Harburn Leasing Agency Ltd. ( 1972 ), 25 D.L.R. (3d) 6o4.

Under Order I I, rule I (ee) of the Supreme Court of British Columbia, service of a writ or of notice of a writ may be allowed out of the jurisdiction where the action is founded on a "tort committed within the jurisdiction." These words must be limited to a wrongful act committed within the jurisdiction and do not extend 
to a case where the wrongful act was committed outside the jurisdiction, but the damage therefrom took place within the jurisdiction. In an action for negligence, the three elements of the tort, namely duty of care, breach of that duty, and damage, must be present within the jurisdiction.

Jurisdiction - Service of Statement of Claim Ex Juris - Action in

Tort Based on Riparian Rights - Wrongful Act Outside Province Causing Damage to Land Within - R. $3^{\circ}(a)$ - Alberta Court of Appeal

Town of Peace River v. British Columbia Hydro and Power Authority, [1972] 5 W.W.R. 35 I.

The plaintiff, a town in Alberta, sued to recover damages by reason of the decrease of its water supply resulting from the construction by the defendant, a British Columbia corporation, of a dam in British Columbia on the Peace River which reduced the flow of water as it passed through the town. An ex parte order for service ex juris was made from which this appeal was taken. It was argued that because the reduction in the flow of water downstream from the dam occurred in British Columbia, the whole subject matter was not land situate within the jurisdiction as required by R. $30(\mathrm{a})$. The Alberta Court of Appeal held that the appeal must be dismissed. In the light of the nature and history of the cause of action, which might be classified as a tort based upon the plaintiff's riparian rights, it was clear that the whole subject matter was "land within Alberta" within R. 30(a).

Jurisdiction - Tort - Service Ex Juris - Saskatchewan Court of
Appeal

Moran et al. v. Pyle National (Canada) Ltd., [1972] 5 W.W.R. $45^{6 .}$

Appeal was allowed from a judgment granting an application for leave to commence a tort action against the appellant in Saskatchewan and for service ex juris, [1972] 3 W.W.R. 16r. The tort was committed in Ontario where the defendant corporation was resident. The court found that the judge had exercised his discretion under section 54 of the Saskatchewan Queen's Bench Act upon the erroneous understanding that that section enlarged the rules as to 
jurisdiction of the court to allow service out of the jurisdiction. Section 54 provides that no action shall be brought in Saskatchewan for damages in respect of a tort committed outside the province except by special leave of the court or a judge. As such, it does not grant jurisdiction but rather allows the court to decline jurisdiction in an area where there had previously been an unqualified right to bring action in Saskatchewan (i.e., where the defendant could be served within the territorial jurisdiction, no matter where the tort was committed).

In general, in an action in personam, the rules as to the legal service of a writ define the limits of the court's jurisdiction. The Rules of Practice and Procedure provide for allowing service out of the jurisdiction. However, there is no jurisdiction in the courts to permit service outside the boundaries of the province except as provided for in the Rules. The order for service made was held to be improper since it could not be allowed under the Rules and since it was predicated upon the invalid premise that section 54 was an enabling section. Furthermore the court found that the judge when exercising his discretion to grant leave under section 54 had failed to take into consideration that no order could be made for service $e x$ juris.

\section{Jurisdiction - Service Ex Juris - Forum Conveniens - Ontario High Court}

Bonlyn Products Ltd. v. Amer. Home Products Corpn., [1972] I O.R. 640 .

Where an American parent company of a wholly-owned Canadian subsidiary is a necessary and proper party to an action brought in Ontario, the principle of the corporate veil cannot be applied in determining whether Ontario is the forum conveniens.

\section{Jurisdiction - Proper Law of Contract - Application for Stay- Saskatchewan Court of Queen's Bench}

E. K. Motors Ltd. v. Volkswagen Can. Ltd., [1972] 2 W.W.R. 7oo.

Plaintiff sued on a contract which contained a clause reading "This Agreement is subject to the laws of the Province of Ontario and to the exclusive jurisdiction of her Courts." The defendant applied for a stay on the ground that the court did not have jurisdiction. In dismissing the application the court held that although 
a clause ousting jurisdiction was not, in law, considered contrary to public policy, such a clause was not necessarily binding: where there was no substantial difference between the law of Ontario and that of Saskatchewan, where there was no question but that a fair trial might be had, and that the balance of convenience and the saving of expense clearly pointed to the desirability of trial in Saskatchewan, plaintiff should be permitted to proceed there.

\section{Procedure - Lis Pendens - Stay of Actions - British Columbia Supreme Court}

Hume $\&$ Rumble v. Commonwealth Construction Co. Ltd., [1972] 4 W.W.R. 546 .

A motion to stay two actions in the British Columbia Supreme Court as vexatious, oppressive, and an abuse of the process of the court on the ground that an action between the same plaintiff and defendant concerning the same subject matter and claiming the same relief was pending in a Manitoba County Court was dismissed. The plaintiff, a British Columbia corporation, was the subcontractor and the defendant, also a British Columbia corporation, was the general contractor for a building project in Manitoba. The action pending in the Manitoba County Court was in respect of work and materials supplied to the defendant and was commenced under the Manitoba Mechanics Lien Act, R.S.M., I970, c. M-8o. The actions in the British Columbia Supreme Court sounded in contract and in the alternative quasi-contract or quantum meruit.

The question of whether a valid subsisting contract existed with respect to the work performed was at issue in both actions. The judge hearing this motion accepted evidence to the effect that under the law of Manitoba it remained an open question whether a valid lien can be established on a claim merely in quasi-contract. Therefore the possibility existed that the plaintiff would be unable to enforce a claim under the Manitoba Mechanics Lien Act.

Applying the principles with respect to abuse of process and the prosecution of suits in two jurisdictions, the court stressed that to justify a stay, the burden of showing that the action was vexatious and that the stay will not cause injustice to the plaintiff lies on the defendant. Where there is a fair possibility, as here, that the plaintiff may have an advantage by proceeding in one jurisdiction notwithstanding that an action is pending in another, he will be allowed to do so. 
Jurisdiction - Lis Pendens - Procedure - Torts - Ontario High Court

Kraft et al. v. The Queen in the right of the Province of Ontario et al., [1972] 3 O.R. 684.

An application to strike out paragraphs of a statement of claim as an abuse of process on the ground that the action was premature was dismissed notwithstanding the fact that the precise amount claimed in an action for indemnity or contribution was dependent upon the outcome of proceedings in another jurisdiction and had not yet been finally determined.

The action arose out of an accident involving a series of collisions on Burlington Skyway following a freezing rain. The plaintiff in this action were the owners and the driver of a public transit bus which had collided with a second vehicle resulting in serious injuries to several passengers. The passengers who claimed to have suffered injuries brought their actions for damages in the State of New York but the litigation had not yet reached judgment. Under the procedure that governs the courts of New York State, there is no provision for joinder of third parties from whom contribution or indemnity is sought. The bus company accordingly sought relief in Ontario with respect to these New York claims alleging negligence on the part of the second vehicle and of the Highways Department and claiming contribution and indemnity for any liability, damage, or expense arising out of the collisions. The court held that section 3 of the Negligence Act, R.S.O., 1970, c. 296 protects the plaintiff insofar as the assertion of a right to contribution and indemnity is concerned, notwithstanding that the precise amount with respect to which relief is sought has not been finally determined.

Lis Pendens - Compétence des Tribunaux - Code de Procédure Civile, art. ${ }_{16} 6_{5}-Q u e ́ b e c$, Cour Supérieure

Unger v. Rosenfeld et autres et Pronghorn Petroleum Corporation Ltd. et Guaranty Trust of Canada, [1972] C.S. 673 .

L'existence d'un recours intenté à l'étranger ne peut créer litispendance. 
Procédure - Compétence des tribunaux - Assignation pour interrogatoire à Montréal - Accident en Ontario - Deux Actions pendantes en Ontario - Siège Social du Défendeur en Ontario. Code de Procédure civile, art. $282-Q u e ́ b e c$, Cour d'Appel

Cornwall Chrysler Plymouth Ltd. v. Lapolla et Autres, [1972] C.A. 875 .

Une personne résidant en Ontario ne peut être contrainte de comparaitre comme témoin au Québec s'il y a une autre action pendante pour la même cause dans la Province d'Ontario.

Marine Marchande - Procédure - Validité de la clause compromissoire de la charte partie - Article 95I du Code de Procédure Civile - Cour fédérale, Division de première instance

Le Syndicate de Normandin Lumber Ltd. c. Le navire Angelic Power et al., [1971] C.F. 263.

Par une charte-partie signée à Londres le 4 janvier 1970, la demanderesse affréta le navire défendeur. La chartepartie prévoyait que tout différend entre les propriétaires et les affréteurs devait être réglé par des arbitres à Londres. Le 28 janvier 1970, la demanderesse intenta une action devant cette cour pour rupture de chartepartie, le capitaine du navire ayant refusé de signer les connaissements relatifs à la cargaison chargée à Québec.

La Cour fédérale décida que bien que l'article $95^{1}$ du Code de procédure civile du Québec reconnaisse la validité de la clause compromissoire, cette dernière ne peut exclure la compétence de la Cour fédérale; en conséquence, l'action ne peut être rejetée mais seulement suspendue jusqu'à l'arbitrage.

La Cour fédérale s'exprima ainsi :

La première question que soulève cette affaire est celle de la validité et de l'effet de la clause compromissoire dont se prévalent les défendeurs.

Dans l'affaire National Gypsum Co. c. Northern Sales Ltd., [ 1964] R.C.S. 144, la Cour suprême du Canada a confirmé une décision de la Cour de l'Echiquier siégeant en amirauté, qui avait rejeté une requête comme celle qui m'est soumise pour le motif qu'une clause compromissoire comme celle dont se prévalent les défendeurs serait nulle et contraire à l'ordre public. Pour en venir à cette conclusion, la majorité de la Cour a d'abord considéré qu'une clause compromissoire est une convention relative à la procédure et 
que, en conséquence, sa validité doit être déterminée par la lex fori. Comme il ne se trouvait, dans les règles en vigueur, aucune disposition concernant cette matière, il fallait, suivant la règle de pratique 2( 1 ) $(b)$ des Règles de la Cour de l'Echiquier, se référer au droit du Québec, où la cause d'action avait pris naissance, pour apprécier la validité de la clause. Et c'est parce que le droit de la province de Québec condamnait les clauses compromissoires comme contraires à l'ordre public que la Cour suprême en est venue à la conclusion qu'il ne fallait pas, dans l'affaire qui lui était soumise, donner effet à la clause compromissoire.

Comme je me considère lié par cette décision, je devrais, si le droit de la province de Québec n'avait pas été modifié depuis qu'elle a été rendue, déclarer que la clause compromissoire dont se prévalent les défendeurs est nulle et, en conséquence, rejeter la requête qui m'est soumise. Mais il arrive que le droit québécois n'est plus, depuis 1965 , ce qu'il était auparavant. Cette année-là, en effet, la législature a édicté un nouveau Code de procédure civile qui, à l'Article 95 I réglemente expressément la clause compromissoire:

951. La clause compromissoire doit être constatée par écrit.

Lorsque le différend prévu est né, les parties doivent passer compromis. Si l'une d'elles s'y refuse, et ne nomme pas d'arbitre, il est procédé à cette nomination et à la désignation des objets en litige par un juge du tribunal compétent, à moins que la convention elle-même n'en ait décidé autrement.

Malgré l'adoption du texte nouveau, certaines décisions de la Cour supérieure du Québec continuent à considérer qu'une clause compromissoire comme celle qui nous intéresse est contraire à l'ordre public (Borenstein c. Trans American Investment and Development Co., [1970] Qué. C.S. 192; Sun and Sea Estates Ltd. c. Aero-hydraulics Corp., [1968] Qué. R. P. 2 10), mais ces décisions m'apparaissent mal fondées, car je ne vois pas comment le législateur québécois aurait pu réglementer la forme et l'effet d'une convention dont il n'admettrait pas la validité. D'ailleurs, l'opinion qu' expriment ces quelques décisions n'est pas partagée par tous les magistrats québécois (Singer Plumbing and Heating Co. c. Richard, [1968] Qué. B.R. 547; Mobilcolor Productions c. Gula, [ I968] Qué. R.P. 22 ; Morin c. Travelers Indemnity Co., [1970] Qué. C.S. 84). Elle ne l'est pas davantage par les auteurs qui ont étudié ce problème: John E. C. Brierley, Aspects of the Promise to Arbitrate in the Law of Quebec, 1970 Revue du Barreau, p. 473; Emile 
Colas, Clause compromissoire, un compromis et arbitrage en droit nouveau, 1968 Revue du Barreau, p. I29.

Je crois donc qu'une clause compromissoire comme celle qui m'est soumise est aujourd'hui valide en droit québécois et que, en conséquence, je ne saurais en prononcer la nullité.

Mais, ici, un autre problème se soulève. $\mathrm{Si}$, comme l'a décidé la Cour suprême dans l'affaire National Gypsum, il faut, dans un procès où la cause d'action a pris naissance au Québec, s'en remettre à la loi québécoise pour apprécier la validité de la clause compromissoire, il semblerait logique qu'il faille également s'en remettre au droit de cette province pour en apprécier l'effet. Or, suivant le droit québécois, lorsque des parties à un contrat ont convenu de soumettre à l'arbitrage des différends qui pourront les opposer, les tribunaux sont incompétents à connâitre de pareils litiges. En droit québécois comme en droit français (Dalloz: Répertoire de droit civil, $v^{b o} \mathrm{com}$ promis, no I 26 et suivants), la clause compromissoire a pour effet de limiter la juridiction du tribunal. C'est pourquoi, dans le cas où une partie intente des procédures judiciaires pour faire trancher un différend qu'elle a convenu de soumettre à l'arbitrage, les tribunaux, à moins que l'autre partie n'accepte de révoquer la clause compromissoire, se déclarent incompétents et rejettent purement et simplement l'action. Auto Fabric Products Co. c. Kaplan Construction Co., [1949] Qué. B.R. 241, Mobilcolor Productions Inc. c. Gula, [1968] Qué. R.P. 22; Morin c. Travelers Indemnity Co., [ 1970] Qué. C.S. 84. Donc, si, dans une affaire comme celle-ci, il fallait se référer au droit québécois pour déterminer l'effet de la clause compromissoire, il faudrait dire qu'une pareille convention a pour effet de soustraire à la juridiction de la Cour des litiges qui, suivant la loi, sont de sa compétence. Or, une pareille conclusion m'apparaît inacceptable. Les lois qui définessent la compétence de cette Cour et de celle qu'elle a remplacée sont des lois d'ordre public auxquelles les citoyens ne peuvent se soustraire. Et si, en common law, la clause compromissoire est depuis longtemps tenue pour valide, c'est parce que l'on considère 'que cette convention n'a pas pour effet d'exclure la compétence des tribunaux. Ainsi, dans l'affaire Atlantic Shipping \& Trading Co. c. Louis Dreyfus and Co., [1922] 2 A.C. 250, Lord Dunedin disait à la page 255:

[Traduction] Vos Seigneuries, sous l'empire de l'ancien droit on a souvent soutenu que la clause compromissoire était nulle parce qu'elle excluait la compétence des tribunaux, mais cette thèse fut finalement abandonnée dans l'arrêt Scott c. Avery 5 H.L.C. 8 I I. Selon mon inter- 
prétation de cet arrêt, on ne peut plus dire qu'une telle clause exclue la compétence du tribunal; au contraire, on invoque cette compétence pour la faire observer et il n'y a rien de mal à ce que des personnes conviennent que des différends qui pourraient survenir entre eux soient réglés par arbitrage. Il s'ensuit que la disposition en question est acceptable dans la mesure où elle prévoit l'arbitrage.

La législature d'une province peut bien, si elle le désire, reconnaître aux citoyens le droit de se soustraire à la jurisdiction des tribunaux qui relèvent de sa propre compétence législative. Cependant, le législateur provincial n'a pas le pouvoir de permettre que l'on se soustraie à la juridiction des tribunaux dont la compétence est définie par le parlement fédéral. Il est donc impossible qu'une clause compromissoire dont le droit du Québec reconnaît la validité ait pour effet de soustraire un litige à la compétence de cette Cour ou de celle qui l'a précédée. On ne peut donner effet à des clauses compromissoires que dans la mesure où elles ne portent pas atteinte à la juridiction de cette Cour. De cela il résulte qu'une clause compromissoire comme celle dont il s'agit ici ne peut pas avoir pour effet de modifier la compétence de la Cour et que, pour ce motif, la Cour, lorsqu'elle est saisie d'une requête comme celle-ci, ne doit pas rejeter l'action pour cause d'absence de juridiction, mais peut seulement ordonner la suspension des procédures.

Pour un commentaire voir Etienne Croteau (1972), $32 \mathrm{R}$ du B. 298. Aussi J.-G. Castel, Quelques questions de procédure en droit international privé québécois (197 I), 3 I R. du B. I34, aux pp. I 39-45.

\section{Procedure - Foreign Joint Venture - Registration - Nova Scotia County Court}

Fischbach $\mathbb{E}$ Moore of Canada Ltd. et al. v. Gulf Oil Canada Ltd. et al. ( 972 ), 23 D.L.R. (3d) 606.

A joint venture of federal and foreign corporations cannot bring an action in Nova Scotia to enforce a lien for materials and labour supplied in performance of a contract made in part in that province unless it is registered under the Partnerships and Business Names Registration Act (N.S.). 
Caution Judicatum Solvi - Code de Procédure Civile, arts. 65, 67, 152. Québec, Cour Supérieure

Schock v. St. Pierre, [1972] R.P. I55.

La présence d'un codemandeur résidant au Québec ne fait pas perdre au défendeur le droit d'exiger du demandeur étranger le cautionnement pour les frais.

Divorce Action - Security for Costs - Cross Demand Code of Civil Procedure, art. 65-Quebec Superior Court

Dame Bedel v. Bedel, [1972] C.S. 7 II.

Since the entry into force of the new Code of Civil Procedure, the question whether a non-resident defendant who includes a cross demand with his defence should be obliged to put up security for costs has been a controverted one. However the court held that the request for security should be dismissed as a cross demand is more an incident in a single action than a new action itself.

Seizure in Garnishment-Banking-Branches-Jurisdiction Over Persons and Property - Quebec Provincial Court

Equity Accounts Buyers Ltd. v. Jacob et la Banque Royale du Canada, [1972] R.P. 326.

In this case, the plaintiff obtained judgment in the Provincial Court in Montreal against a debtor domiciled in Ontario. The plaintiff then made a seizure in garnishment against the bank account of the debtor at a branch of the Royal Bank of Canada in Ottawa and the writ was served on the aforesaid branch as well as upon the head office of the bank in Montreal. The bank either through its head office or its branch, did not answer the seizure by garnishment and plaintiff obtained judgment by default against the tierce saisie which later attacked this judgment by a requête en revocation which was granted.

The court held that a writ of garnishment does not bind and affect the property of a bank situated at its head office when the judgment debtor's account is located in a branch outside the province.

The service of a writ of garnishment on the branch of the bank in Ottawa was not valid and binding.

When a seizure is issued in the hands of a bank proposing to 
attach the bank account or other assets of any defendant, it is only the assets of the defendant that are found in that branch that can be subject to the seizure; it does not extend to other accounts at other branches. Thus the obligation of the bank is only to pay the money at the branch where it has been deposited and conversely the depositor cannot demand that the money be paid at any other branch.

Quebec courts have no jurisdiction to order someone from another province to come to Montreal and declare what he owes the debtor.

Conditional Sale - Removal of Object Sold - Effect-Alberta District Court

Gen. Motors Accept. Corpn. v. Prestie, [1972] 3 W.W.R. 534.

Where a contract for the conditional sale of an automobile, made in Ontario, is registered in the Motor Vehicle Branch within 2 I days of the seller receiving notice of its permanent removal into Alberta, the relief afforded by the Conditional Sales Act, R.S.A., 1970, c. 6I, s. $14(2)$ is available to him in defeasance of the rights of bona fide purchasers for value without notice whose rights stem from the fraudulent acts of the conditional purchaser and accrued before the conditional vendor "received notice." There is no requirement in law that a conditional vendor exercise any particular degree of vigilance in tracing an itinerant machine which has been removed from the province where it was first sold, as for instance, by searching the registries of other provinces.

Foreign Conditional Sales Contract-Repossession-Effect of Ontario Legislation - Ontario High Court

Morin v. General Motors Acceptance Corp. of Canada Ltd. (1972), 27 D.L.R. (3d) 46.

Under the terms of a conditional sales contract entered into in Quebec between Quebec residents, repossession of the motor vehicle purchased was effected in Ontario by the finance company. Section 35 of the Ontario Consumer Protection Act, R.S.O., 1970, c. 82 provides that where $2 / 3$ of the purchase price of the goods as fixed by contract has been paid, any provision in a contract allowing for repossession is not enforceable except by leave of a county court 
judge. Here since $2 / 3$ of the purchase price (which was found to include finance charges) had not been paid, leave was not required. However, the judge remarked in obiter that had that amount been paid, section 35 would have applied to any repossession effected in Ontario notwithstanding that it was under a contract entered into in Quebec between Quebec residents. Section 36 of the Ontario Consumer Protection Act requiring a clear statement in writing of certain terms of the contract was held to be inapplicable to a transaction entered into in Quebec between parties resident in Quebec when credit was granted.

Sale - Currency - Goods Sold and Delivered from Germany Payable in U.S. Funds - Judgment Obtained in U.S. FundsQuebec Court of Appeal

Carsley Silk Co. Ltd. v. Koechlin Baumgartner $\&$ Cie., [1972] G.A. 267 (1972), 23 D.L.R. (3d) 255 .

According to sections I I and I2 ( I) of the Currency Mint \& Exchange Act, R.S.C., 1970, c. 39 , a person cannot be condemned to pay a sum of money for goods sold and delivered in the currency of a foreign country.

This rule applies to both public accounts and private agreements.

\section{Arbitration - Contract - Law Applicable - Jurisdiction - Sas- katchewan Court of Appeal}

Re O'Brien and C.P.R. (1972), 25 D.L.R. (3d) 230.

Where the intention of the parties respecting the proper law of a contract is not expressly stated in such contract, it may be inferred from the terms and nature of the contract and the surrounding circumstances or, failing that, by referring to the system of law with which the contract has its closest and most real connection. Although the collective agreement did not expressly state the law to govern the arbitration procedure, it may be inferred that the parties provided for the establishment of the Canadian Railway Office of Arbitration in Montreal in order to overcome the problems necessarily inherent in determining the applicable law to arbitration procedure in a collective agreement connected with more than one jurisdiction, and, in so doing, intended that the arbitrator, in arbitration thereunder, would be governed by the laws of Quebec and the courts of that province. 
Vicarious Liability - Actionable Act by Lex Fori and Lex Loci Delicti-Quebec Court of Appeal

Ford Motor Co. of Canada Ltd. v. Dame Lagacé and Zimone, [1972] C.A. 455 .

The appeal from the award of a lower Quebec court to the widow of the victim of a motor accident which occurred in the province of Ontario was dismissed with the finding that there was no real conflict between Ontario and Quebec law on the facts of this case. The victim was a gratuitous passenger in a car owned by the appellant and driven by a man who was not an employee of the appellant company. The appeal court upheld the finding that there had been gross negligence on the part of the driver and that the car was driven with the implied consent of the company. Accordingly the act was actionable in both Ontario (Highway Traffic Act, 1960, c. 172, S. 105(1) and (2)) and Quebec (Highway Victims Indemnity Act, R.S.Q., I964, c. 232, s. 3 (a), (b), and (c)).

\section{Wills - Non-resident Executor - Probate - Alberta Court of Ap- peal}

Re Amery Estate (1972), 25 D.L.R. (3d) 126.

In Alberta the power to grant probate to a non-resident executor, even an alien non-resident, exists as a necessary inference from $s$. 6(2) of the Administration of Estates Act, R.S.A., 1970, c. I which provides that a bond is not required on application for probate where the applicant is the executor under the will and resident in Alberta.

Form of Wills - Probate - Movables - Ontario Court of Appeal Re Bishop, [1972] I O.R. I83.

A holograph will executed in Ontario by a person domiciled in Ontario at the time of the will's execution is nevertheless valid and admissible to probate so far as it relates to an interest in movables within Ontario despite its failure to comply with the formalities required by s. I I of the Wills Act, R.S.O. 1960, c. 433 (now R.S.O. I970, c. 499), where it is made as permitted by s. I9 (4)(C), in accordance with the law in force at the time of its making in the place where the testator had his domicile of origin. 
Domicile of Choice - Acquisition-Unlawful Residence under Immigration Act - Ontario High Court

Jablonowski v. Jablonowski, [1972] 3 O.R. 4 Io.

The petitioner was held to have acquired a domicile of choice in Canada for the purposes of the Divorce Act notwithstanding that he could not be considered domiciled in Canada for purposes of the Immigration Act since his entry and therefore his residence in Canada were unlawful. The court held that since the Divorce Act did not define domicile, the common law principles with respect to the acquisition of a domicile of choice applied. Therefore, both the animus manendi and factum being present, the petitioner had acquired the domicile of choice in Canada at common law. The definition of domicile in the Immigration Act merely indicates the degree of connection with Canada which is required for immigration matters and does not extend beyond the purposes of that Act.

Indians-Meaning of "Ordinarily resident"-Indian Act-Manitoba Queen's Bench

Canard v. Attorney General of Canada and Rees, [1972] 4 W.W.R. 618.

The words "ordinarily reside" are not defined in the Indian Act but have been the subject of frequent judicial interpretation. The authorities are to the effect that a person can have more than one "ordinary residence" according to the particular facts. The court quoted Rand J. in Thomson v. M.N.R., [ 1946] S.C.R. 209, at 224, to the effect that:

The gradation of degrees of time, object, intention, continuity and other relevant circumstances, shows, I think, that in common parlance "residing" is not a term of invariable elements, all of which must be satisfied in each instance. It is quite impossible to give it a precise and inclusive definition. It is highly flexible, and its many shades of meaning vary not only in the contexts of different matters, but also in different aspects of the same matter. In one case it is satisfied by certain elements, in another by others, some common, some new.

The expression "ordinarily resident" carries a restricted signification, and although the first impression seems to be that of preponderance in time, the decisions on the English Act [i.e., the Income Tax Act of the United Kingdom] reject that view. It is held to mean residence in the course of the customary mode of life of the person concerned, and it is contrasted with special or occasional or casual residence. The general mode of life is, therefore, relevant to a question of its application. 
For the purposes of income tax legislation, it must be assumed that every person has at all times a residence....

And at 225:

But in the different situations of so-called "permanent residence", "temporary residence", "ordinary residence", "principal residence" and the like, the adjectives do not affect the fact that there is in all cases residence; and that quality is chiefly a matter of the degree to which a person in mind and fact settles into or maintains or centralizes his ordinary mode of living with its accessories in social relations, interests and conveniences at or in the place in question. It may be limited in time from the outset, or it may be indefinite, or so far as it is thought of, unlimited. On the lower level, the expressions involving residence should be distinguished, as I think they are in ordinary speech, from the field of "stay" or "visit".

"Ordinarily resident in the constituency" - Meaning for the Purpose of Elections - Saskatchewan Court of Appeal

Re Quandt and Guy (1972), 26 D.L.R. (3d) 489.

Persons working temporarily in the constituency and having a permanent residence elsewhere are not qualified to vote under the Saskatchewan Election Act, S.S., I97 I, c. 10, s. 28(2).

\section{Marriage - Validity - Foreign Divorce - Expert Evidence- Ontario High Court}

Viccari v. Viccari (1972), 7 R.F.L. 24I, [1972] 3 O.R. 706.

In a claim for moneys owing under a separation agreement, the issue of the validity of a marriage was resolved in favour of the plaintiff as a consequence of the finding that a previous Mexican divorce decree would be recognized in Ontario since it would be valid in New York state, the place of domicile of the divorced husband at the time of the decree of divorce. The trial judge rejected the opinion of the expert on New York law that it was doubtful that the Mexican decree would have been recognized as valid in New York state at the time of granting of the decree and referred to a case quoted by the expert witness to substantiate his conclusion that such a decree would in fact have been valid. 
Divorce - Jurisdiction - Ontario High Court

Dimitrijevic v. Dimitrijevic, [1972] 3 O.R. 335, 28 D.L.R. (3d) 177 .

An Ontario court has no jurisdiction to entertain a petition for divorce or to grant corollary relief by a wife having a domicile of origin in Yugoslavia but residing in New York, even though her husband is domiciled in Ontario. The domicile of the wife is to be determined as if she were unmarried.

Divorce-Jurisdiction - Change of Domicile after Petition but before Trial - British Columbia Supreme Court

Weston v. Weston, [1972] 2 W.W.R. 402.

Proceedings for divorce, commenced in the jurisdiction of the petitioner's then domicile, can be continued there notwithstanding a change of domicile before trial.

Divorce - Jurisdiction - Lis Pendens - British Columbia Supreme Court

Barlow v. Barlow (1972), 26 D.L.R. (3d) 379.

Although s. 5(2) (a) of the Divorce Act, R.S.C., 1970, c. D-8, provides in part that "if petitions were presented on different days and the petition that was presented first is not discontinued within thirty days after the day it was presented, the court to which a petition was first presented has exclusive jurisdiction ...," the language of the section should be restricted to cases where one petition is commenced by one spouse and a second petition is commenced by the other spouse, since the object of the section is to prevent more than one contest between the parties. Therefore, the mere existence of an earlier petition presented by the same petitioner is not a bar to another court assuming jurisdiction under a later petition.

Maintenance - Recognition of Foreign Divorce - Status - Estoppel - Ontario County Court

Re Reid and Reid, [1972] I O.R. 554, 23 D.L.R. (3d) $53^{8}$.

Where an applicant brought proceedings under the Deserted Wive's and Children's Maintenance Act of Ontario, the respondent 
was not estopped from questioning his Nevada marriage to the applicant on the ground that while domiciled in Ontario he had divorced his first wife in Michigan. The applicant was not legally married to the respondent and therefore unable to bring such proceedings. While many cases have held that one spouse who obtains an invalid divorce is precluded from attacking the validity of the decree, they have dealt uniformly with matters of money or property as between spouses or their representatives. In this case the status of the respondent is at stake. He may be estopped under some circumstances from denying the validity of the Michigan divorce, but he cannot be estopped from denying the validity of his subsequent marriage.

\section{Infants - Custody - Jurisdiction - Ontario High Court}

Re Vadera and Vadera, [1972] i O.R. 44I.

The court made an order under the Infants Act, R.S.O., I970, c. 222, requiring the father to return the child to the custody of the applicant wife pending trial of an issue as to custody where the father respondent had removed the child from the province without the consent of the mother but himself remained within Ontario. Habeas corpus was not found to be the appropriate remedy in the circumstances.

Custody - Jurisdiction - New Brunswick Supreme Court, Queen's Bench Division

Adams v. Adams (1972), 4 N.B.R. (2d) 275.

The court held that it had jurisdiction to make a custody award pursuant to the corollary relief sections of the Divorce Act notwithstanding that the children in question were temporarily absent from the jurisdiction having been surreptitiously removed to British Columbia by the respondent wife. To all intents and purposes a court sitting in such matters acts as a Federal Court.

In addition, under its inherent provincially-derived jurisdiction, a court has jurisdiction over the custody of a child ordinarily resident within its territory, even though the child may be temporarily outside. 
Divorce - Jurisdiction - Interim Custody - Ontario Court of
Appeal

Johnson v. Johnson et al., [1972] I O.R. 2 I 2.

A court in divorce proceedings has jurisdiction to entertain an interim custody application notwithstanding that immediately prior to the application one party, sensing defeat, takes de facto custody and leaves the jurisdiction, provided he resided within it before such move.

\section{Infants - Custody - Jurisdiction - Ontario Court of Appeal}

Re Ridderstroem and Ridderstroem, [1972] 2 O.R. II3.

The appeal from an order refusing to grant custody of a child to the father or to direct the trial of an issue as to custody was dismissed. The parents of the child were domiciled in Denmark where the mother instituted proceedings for custody following a separation. At the same time, the father forcibly removed the child from Denmark and set up residence in Toronto (having entered under a false passport) but he was refused landed immigrant status.

The courts of the English countries operating under the common law system will look with great disfavour on any attempt to flout the invoked jurisdiction of a proper court in a foreign country unless the paramount interests of the child demand that such be done - and such paramount interest of the child is to be demonstrated by cogent proof that to leave the child with the parent which had custody in the country of original jurisdiction will seriously endanger the child's welfare. Having regard to the age and sex of the child and the precarious nature of the father's status in Canada, the above onus was not satisfied. In addition, there were serious charges and counter-charges of misconduct between the parties which would affect the question of custody and which ought to be heard before a Danish court since they can only properly be decided by viva voce evidence.

Custody - Jurisdiction - Removal of Children from Foreign Jurisdiction during Proceedings Involving Custody - Manitoba Court of Queen's Bench

Prossor-Jones v. Prossor-Jones (1972), 7 R.F.L. 150.

In a general sense, children are wards of the superior courts with 
jurisdiction in the district in which they reside. In a special sense, when proceedings are started in a court which involve their status, either in regard to questions of custody, or in regard to questions of adoption, or other like matters, they become especially wards of the court. To physically remove them from the jurisdiction of that court is an act which cannot be condoned or tolerated. Therefore, the parent who removed them must not obtain benefit from such an improper action and the Manitoba court will order them to be returned.

\section{Infants - Maintenance - Jurisdiction - Ontario High Court \\ Emerson v. Emerson, [1972] 3 O.R. 5.}

The Ontario court held that it had jurisdiction to entertain an application for maintenance under the Infants Act, R.S.O., 1970, c. 222, notwithstanding that maintenance to be paid in respect of the particular child of divorced parents had already been set by the Supreme Court of New Brunswick in the decree absolute. A divorce decree in the superior court of one province under the Divorce Act, R.S.C., 1970, c. D-8, which gives corollary relief in respect of children of the marriage under section ro of that Act, does not inhibit the exercise of any ordinary jurisdiction in another province for the custody, maintenance, care, or upbringing of such children there. The future rights of children of divorced parents do not necessarily depend on the state of marriage or the condition of divorce between their parents. In their capacity as citizens and children, they are entitled to the protection of the provincial superior courts exercising the prerogative of the Crown in the right of the province as parens patriae.

It may well be, however, that no court other than the court which originally made an order under the Divorce Act would have jurisdiction either to make a fresh order or to vary the decrees or orders already made. It may well be true also that a party to a divorce petition enjoying rights or benefits under such a decree or order, cannot continue to enjoy those rights or benefits in any province if he or she elects to seek to vary them by invoking normal provincial jurisdiction without regard to the exercise of the divorce jurisdiction in his or her favour. 
Affiliation Proceedings - Jurisdiction - Ontario Provincial Court

Woods v. Goldamer (1971), 7 R.F.L. I81.

An Ontario court has jurisdiction to hear an affiliation application brought by a non-resident mother against a putative father resident in Ontario in respect of a child conceived and born outside the province. The residency of the father is the essential test for jurisdiction.

Foreign Maintenance Order - Registration - Other Relief - Ontario Court of Appeal

Re Katz and Kaye (1972), 27 D.L.R. (3d) 33, [1972] 2 O.R. 854. An appeal from an order dismissing an application to set aside the registration of a Michigan judgment under the Reciprocal Enforcement of Maintenance Orders Act, R.S.O., 1970, c. 403 was dismissed.

The onus of showing that the appellant was not domiciled in the State of Michigan at the time of the divorce action and that he did not attorn to the Michigan jurisdiction lies upon the appellant and was not fulfilled here.

In addition the court held that registration of a judgment under the Act is merely one procedure for enforcing a judgment for maintenance and does not preclude the person registering from other relief.

Reciprocal Maintenance Orders - Enforcement - British Columbia County Court

Attorney General v. Buschkewitz, [1970] 3 W.W.R. I 7.

A German court has no jurisdiction to issue a "final" order against a person who was served with process in British Columbia. Thus enforcement of the order will be refused in British Columbia.

Foreign Maintenance Order - Enforcement - Northwest Territories Magistrate's Court

Bianowsky v. Bianowsky, [1972] 6 W.W.R. 679.

A probation officer has no authority to enforce an Alberta maintenance order registered in the Northwest Territories. He is not "an 
officer of the Court" as those words are used in The Maintenance Orders (Facilities for Enforcement) Ordinance, R.O.N.W.T., I956, c. 63 .

Foreign Judgment - Registration - Time Limitation - Alberta Court of Appeal

McCormack v. Starr, [1972] I W.W.R. 239.

A defendant against whom a judgment has been registered pursuant to an ex parte order under the Reciprocal Enforcement of Judgments Act, R.S.A., 1970, c. $3^{12}$ may apply to set it aside within one month after he has had notice of the registration. However, the notice of motion must be both filed and served within that time.

Foreign Judgment for Arrears of Maintenance - Finality - Public Policy - British Columbia Supreme Court

Patton v. Reed, [1972] 6 W.W.R. 208.

The court was willing to enforce an Idaho judgment for an amount representing twenty years arrears in maintenance payments consolidated into a lump sum even though in British Columbia a judgment for arrears of maintenance in excess of one year could not be awarded or enforced. Since the Idaho judgment was for a lump sum and not for periodical payments, it was considered final and conclusive. Thus its enforcement did not offend the public policy of British Columbia. 